\title{
Pengaruh Bimbingan Karier terhadap Efikasi Diri dalam Pengambilan Keputusan Karier pada Siswa
}

\author{
Dyan Widyaningrum ${ }^{1} \mathcal{E}$ Thomas D. Hastjarjo ${ }^{2}$ \\ 1,2Fakultas Psikologi Universitas Gadjah Mada
}

\begin{abstract}
This study aimed to determine the effect of career guidance on the self-efficacy in career decision-making with mastery goal orientation as co-variables. The research design used quasi experiment consisting of two groups: the experimental group and the control group. The experimental group received treatment (career guidance). Self-efficacy in career decision-making was measured using the questionnaire of self-efficacy in career decisionmaking and mastery goal orientation was measured with a scale of mastery goal orientation. Career guidance module was administered to the experimental group. Subjects in this study amounted to 48 students a class XI of SMA X in Yogyakarta. Analysis of covariance was used to analyse the data and resulted in no relationship between mastery goal orientation and self-efficacy in career decision making ( $p>.05)$. Therefore the analysis turned to mixed anova resulting that there was the effects of the career guidance to self efficacy in career decision making $(\mathrm{F}=104.074 ; \mathrm{p}<0.05)$.
\end{abstract}

Keywords: career guidance, self-efficacy

Abstrak. Penelitian ini bertujuan untuk mengkaji pengaruh bimbingan karier terhadap efikasi diri dalam pengambilan keputusan karier dengan orientasi tujuan penguasaan sebagai kovariabel. Rancangan penelitian ini menggunakan eksperimen kuasi yang terdiri dari dua kelompok yaitu kelompok eksperimen dan kelompok kontrol. Kelompok eksperimen yang mendapat perlakuan (bimbingan karier). Efikasi diri dalam pengambilan keputusan karier diukur dengan menggunakan skala efikasi diri dalam pengambilan keputusan karier dan orientasi tujuan penguasaan diukur dengan skala orientasi tujuan penguasaan. Sedangkan bimbingan karier diberikan dengan menggunakan panduan modul bimbingan karier. Subjek pada penelitian ini berjumlah 48 siswa kelas XI SMA X di Yogyakarta. Analisis data yang digunakan dalam penelitian ini adalah design ANCOVA. Hasil korelasi orientasi tujuan penguasaan dengan efikasi diri dalam pengambilan keputusan karier menunjukkan nilai $p>0,05(-0,061)$, yang artinya bahwa orientasi tujuan penguasaan tidak berhubungan dengan efikasi diri dalam pengambilan keputusan karier. Oleh karena itu analisis berubah menjadi MIXED ANOVA. Hasil uji hipotesis menunjukkan nilai $\mathrm{F}=104,074(\mathrm{p}<0,05)$, yang artinya terdapat pengaruh dari bimbingan karier terhadap efikasi diri dalam pengambilan keputusan karier di SMA X di Yogyakarta.

Kata Kunci: bimbingan karier, efikasi diri

${ }^{1}$ Korespondensi melalui artikel ini dapat disampaikan melalui: dyanwidya27@gmail.com

${ }^{2}$ Atau melalui: dickyh@ugm.ac.id 
Karier berpengaruh pada kebahagiaan hidup manusia secara keseluruhan. Oleh karenanya ketepatan memilih serta menentukan keputusan karier menjadi titik penting dalam perjalanan hidup manusia. Keputusan memilih suatu karier dimulai saat individu berada pada masa remaja. Pada usia remaja, sekolah merupakan aspek penting dalam kehidupan karena pendidikan menyiapkan mereka dalam kondisi siap untuk mengambil keputusan karier.

Menurut Santrock (2003), masa remaja adalah masa dimana pengambilan keputusan meningkat. Kebanyakan pengambilan keputusan dibuat oleh para remaja yang mengalami perubahan yang menyulitkan dan tidak berguna. Seringkali remaja hanya mengetahui bahwa mereka menginginkan sesuatu tetapi tidak mengetahui apa yang dibutuhkan, maka perlu bimbingan untuk mengarahkan keinginannya tersebut. Berkaitan dengan karier bahwa remaja mendambakan karier tertentu namun mereka belum memahami karier yang didambakan sesuai dengan kondisi diri, lingkungan serta segala sesuatu yang perlu dilakukan dalam pencapaiannya.

Banyak siswa SMA yang sulit mengambil keputusan karena tidak tahu apa bakat dan minatnya, dan banyak yang belum menemukan potensi dirinya, tidak terbiasa mengambil keputusan sendiri bahkan untuk hal-hal yang terkait dengan kepentingannya, sehingga bingung ketika harus memilih jurusan dan perguruan tinggi. Kesalahan pemilihan pendidikan seperti di atas dapat mengakibatkan kegagalan dalam belajar dan juga dapat berpengaruh terhadap keputusan dalam pemilihan kariernya

Karier merupakan urutan-urutan aktivitas yang berhubungan dengan pekerjaan dari perilaku, nilai serta aspirasi individu selama rentang hidup individu tersebut (Simamora, 2004). Efikasi diri memegang peranan penting dalam pengambilan keputusan karier individu. Taylor dan Betz mempublikasikan artikel mengenai aplikasi efikasi diri dalam psikologi karier (dalam Ardiyanti, 2014). Konsep efikasi diri dalam membuat keputusan karier bukan mengenai konten atau gaya pengambilan keputusan individu tetapi mengacu pada kepercayaan diri individu terhadap kemampuannya untuk membuat keputusan karier dengan tepat. Efikasi diri terhadap pengambilan keputusan karier merupakan keyakinan individu terhadap kemampuan dirinya bahwa ia dapat sukses menyelesaikan tugas-tugas yang berhubungan dengan pengambilan keputusan karier.

Efikasi diri remaja memengaruhi pilihan aktivitas, tujuan dan usaha serta persistensi remaja tersebut. Dengan kata lain, efikasi diri juga memengaruhi pembelajaran dan prestasi akademiknya (Ormrod, 2009). Secara umum Ormrod (2009) menyatakan bahwa efikasi diri remaja sebagai penilaian remaja mengenai kemampuan sendiri untuk menjalankan perilaku tertentu atau mencapai tujuan tertentu. Berdasarkan hasil wawancara awal yang dilakukan Ardiyanti (2014) dalam penelitiannya terhadap 15 orang siswa kelas XII, diketahui bahwa 10 orang dari mereka mengalami keraguan dalam menentukan pilihan program studi. Ardiyanti juga melakukan survey terhadap 157 siswa kelas XI wilayah Yogyakarta, didapat 43\% siswa yang masih belum yakin dan bingung dengan pilihan program studi di Perguruan Tinggi. Penyebab kurangnya efikasi diri dalam pemilihan karier pada siswa adalah kurangnya pemahaman diri, kurangnya wawasan atau informasi karier dan ketidak-mampuan dalam menetapkan 
tujuan dan rencana karier (Ardiyanti, 2014). Hal ini terjadi dikarenakan tidak semua siswa dapat dengan mudah membuat keputusan karier, banyak diantara mereka yang mengalami keraguan dalam mengambil keputusan karier.

Beberapa penelitian mengungkapkan bahwa pengambilan keputusan berhubungan dengan efikasi diri. Pengambilan keputusan yang berhubungan dengan efikasi diri didukung dengan hasil penelitian Burns, Jasinski, Dunn dan Fletcher (2013) dengan judul penelitian Academic Support Services and Career Decision-Making Self-Efficacy in Student Athletes. Penelitian tersebut meneliti hubungan antara evaluasi layanan dukungan akademik dan self efficacy pengambilan keputusan karier atlet mahasiswa. Hasilnya menunjukkan bahwa evaluasi layanan dukungan akademik secara positif berhubungan pada tingkat self efficacy pengambilan keputusan karier. Suatu permasalahan juga dapat timbul karena dipengaruhi oleh efikasi diri yang berhubungan secara tidak langsung terhadap pengambilan keputusan melakukan suatu hal.

Ketidakmampuan individu dalam membuat keputusan karier dapat dipengaruhi oleh efikasi diri terhadap pengambilan keputusan karier (Osipow, 1987; Betz et al, 1996). Efikasi diri yang rendah sehubungan dengan proses pembuatan keputusan karier terkait dengan kebimbangan dalam pembuatan keputusan karier, masalah-masalah dalam mengembangkan identitas vokasional yang jelas, dan ketidakpastian dalam menentukan pilihan yang ditunjukkan dengan seringnya individu berganti-ganti pekerjaan. Efikasi diri yang rendah dapat menghalangi individu untuk mewujudkan ketertarikan-nya terhadap suatu karier karena merasa tidak memiliki kemampuan yang penting bagi kariernya. Mereka juga kurang dapat berkompetisi untuk mendapatkan peker-jaan, kurang berpengalaman, dan tidak tahu apa yang harus mereka lakukan untuk mengatasi rintangan dalam mendapatkan pekerjaan dengan sukses (Collins dalam Lyon \& Kirby, 2000). Hasil penelitian yang dilakukan oleh McNeill, 1990; Luzzo dan Taylor, 1994, menunjukkan efektivitas intervensi karier dalam meningkatkan efikasi diri dalam membuat keputusan karier (dalam Betz \& Luzzo, 1996).

Pengambilan keputusan karier menjadi salah satu tahapan yang harus dihadapi individu dalam perjalanan hidupnya (Brown \& Assiciates, 2007) hal ini menunjukkan bahwa seorang individu harus mampu mengevaluasi dan berhatihati dalam memilih karier, karena konsekuensi yang akan diterima oleh individu tersebut dapat menimbulkan masalah terhadap dirinya (Burns, et al. 2013). Menurut Burns, et al. (2013) dibutuhkan efikasi diri dalam pemilihan karier yang tinggi dari seorang individu, sehingga individu tersebut tidak merasakan menyesal nantinya karena telah salah dalam menentukan pilihan.

Menurut Taylor dan Betz, efikasi diri terhadap pengambilan keputus-an karier memengaruhi area-area dari perilaku pencapaian karier termasuk kemampuan untuk mengejar ketertarikan karier dan tingkatan ketekunan terhadap pencapaian suatu karier (dalam Ardiyanti, 2014). Penelitian-penelitian para ahli mengenai efikasi dalam konteks karier menunjukkan bahwa aplikasi efikasi diri yang paling popular dalam perilaku karier adalah efikasi diri terhadap pengambilan keputusan karier (Betz, Klein \& Taylor, 1996). Hal tersebut mengindikasikan bahwa peneliti lebih banyak melakukan penelitian terhadap efikasi diri yang lain dengan mempertimbangkan pentingnya 
efikasi diri yang dimiliki individu dalam membuat keputusan-keputusan karier.

Kemampuan individu dalam pemilihan karier sangat diperlukan agar individu lebih terarah dan terfokus pada satu pilihan di antara banyak pilihan karier yang diperoleh dari berbagai pengenalan karier, sehingga individu memiliki wawasan yang luas dan tidak mengalami kebingungan dalam memilih karier yang dikehendaki. Banyak remaja yang tidak cukup banyak mengembangkan pilihan karier mereka sendiri dan juga hanya sedikit menerima bimbingan karier dari pembimbing di sekolah mereka (Santrock, 2003). Upaya dalam pencegahan dan mengatasi masalah kebingungan dalam merencanakan karier adalah layanan bimbingan karier dari konselor dan guru bimbingan dan konse-ling di sekolah.

Bimbingan karier merupakan program yang dirancang untuk memfasilitasi perkembangan karier terutama pengelolaan kariernya. Bimbingan karier dapat dilakukan secara individual dan kelompok kecil, antara klien dan konselor, yang meng-gunakan alat-alat khusus dengan tujuan membantu individu untuk mendapatkan pengetahuan akan dirinya (self knowledge), pengetahuan lingkungan kerjanya dan mengembangkan keterampilan yang mengantarkan individu menghadapi masa transisi dari sekolah ke dunia kerja.

Herr dan Cramer (dalam Oweini \& Abdo, 2000), mendefinisikan bimbingan karier merupakan suatu program yang sistematis mengenai informasi-informasi yang terkoordinasi dengan konselor, serta pengalaman-pengalaman yang dirancang untuk memfasilitasi pengembangan karier individu dan khususnya pengelolaan karier. Bimbingan karier memfasilitasi individu dalam menghadapi ketidakpastian dalam pengambilan keputusan kariernya.

Peneliti menggunakan bimbingan karier sebagai cara untuk meningkatkan efikasi diri dalam pengambilan keputusan karier siswa. Menurut Juntika (2006) bimbingan karier merupakan bimbingan untuk membantu individu dalam perencanaan, pengembangan dan pemecahan masalah-masalah karier. Bimbingan karier juga merupakan layanan pemenuhan kebutuhan perkembangan individu sebagai bagian integral dari program pendidikan.

Penentuan pilihan karier pada SMA untuk siswa yang mempunyai tingkat kelas lebih tinggi diasumsikan memiliki pengetahuan yang lebih luas mengenai informasi karier, sehingga ia mempunyai sikap dan kemampuan yang lebih baik dalam pengambilan keputusan karier. Hasil penelitian yang dilakukan oleh Glaize dan Myrick (dalam Purnamasari, 2005) menyimpulkan bahwa siswa yang diberi informasi pekerjaan yang lengkap, dapat melihat dunia kerja lebih realistik dan makin berusaha mengembangkan kariernya. Bandura dan Schunk (1984) membuktikan dengan sangat meyakinkan adanya hubungan antara peningkatan pemecahan masalah dengan sistem pemberian infor-masi pekerjaan bagi sekelompok siswa.

Penelitian yang dilakukan oleh Supatmi (2014) tentang pengembangan bahan informasi bimbingan pemilihan karier untuk meningkatkan kemampuan pengambilan keputusan karier mengindikasikan bahwa bimbingan karier bisa dilakukan dengan memberikan informasi karier. Bahan informasi bimbingan pemilihan karier dapat meningkatkan kemampuan pengambilan keputusan karier bahan informasi bimbingan pemilihan karier efektif untuk meningkatkan kemampuan pengambilan keputusan karier siswa 
sekolah menengah kejuruan rumpun jurusan ekonomi. Penelitian tersebut menunjukkan bahwa pentingnya bimbingan karier dalam membantu siswa dalam menentukan karier apa yang akan dipilih.

Kurangnya informasi yang berkaitan dengan pendidikan, jabatan, atau pekerjaan yang cocok dengan kemampuan siswa juga merupakan salah satu penghambat siswa tidak dapat mengambil keputusan kariernya secara tepat. Siswa bingung dengan jurusan yang akan diambilnya apabila akan melanjutkan pendidikannya serta apabila akan bekerja juga tidak tahu pekerjaan yang cocok baginya, sehingga bagi siswa yang tidak melanjutkan sekolah, banyak yang menganggur setelah siswa tersebut lulus dari bangku sekolah (Sukardi, 1994). Siswa yang mengalami hambatan tersebut membutuhkan bimbingan sehingga dapat menggunakan kemampuannya dalam proses penentuan karier. Dalam pemilihan karier yang tepat tentunya harus disesuai-kan dengan minat dan kemampuan dari siswa itu sendiri (Sukardi, 1994).

Efikasi diri dapat ditingkatkan dengan memberikan berbagai macam layanan bimbingan, pelatihan dan lain sebagainya kepada siswa. Layanan bimbingan karier mampu membantu siswa dalam merencanakan kariernya yang dapat memengaruhi efikasi diri dalam pengambilan keputusan karier siswa. Jaffe dan Scott (Kummerow, 1991) berpendapat bahwa dengan siswa merencanakan kariernya siswa akan mampu meningkatkan efikasi diri dalam pengambilan keputusan karier. Perencanaan karier di atas dilakukan dengan lima tahap, yaitu menilai diri sendiri, mengeksplorasi peluang, membuat rencana, melakukan tindakan, dan mengevaluasi hasil. Tahapan di atas dapat membantu siswa dalam merencanakan karier yang sesuai dengan bakat dan minatnya.

Penelitian Santoso dan Fathul (2014), tentang pengaruh berbagai pengetahuan perencanaan karier terhadap efikasi diri dalam keputusan karier mendapatkan hasil bahwa berbagai pengetahuan mampu secara efektif meningkatkan efikasi diri dalam membuat keputusan karier para pencari kerja yang berdampak pada munculnya respon perilaku yang lebih positif terhadap tugas-tugas terkait karier pilihannya.

Fogarty dan McGregor-Bayne (2008), menemukan bahwa terdapat tiga faktor yang dapat memengaruhi efikasi diri dalam pengambilan keputusan karier seorang individu (siswa atlet), yaitu faktor usia, jenis kelamin, dan orientasi tujuan.

Orientasi tujuan (goals orientation) pada pembelajaran memiliki pengaruh meningkatkan efikasi diri pada individu (Wisudaningrum, 2012). Hal ini disebabkan oleh orientasi tujuan pembelajaran akan memberikan pemahaman yang positif, sehingga individu dapat memproses informasi dengan baik. Orientasi tujuan memberikan kerangka mental yang seseorang gunakan untuk menafsirkan dan menanggapi pencapaian dan kegagalan situasi (Dweck \& Leggett, 1988) dan perbedaan individu yang berguna untuk membangun pemahaman terhadap pembelajaran, pelatihan dan hasil kinerja (Zweig \& Webster, 2004). Dweck dan Leggett (1988), menyatakan bahwa orientasi tujuan (Goal Orientation) terbagi atas dua orientasi pada tujuan performa (Performance Goals) dan orientasi tujuan pada pembelajaran (Learning Goals). Berdasarkan preliminary study yang dilakukan oleh Wisudaningrum (2012), lebih mengarah pada orientasi tujuan pembelajaran (Learning Goals). Orientasi ini disebut juga dengan orientasi tujuan pada penguasaan, yang berfokus 
pada peningkatan kompetensi, mendapatkan keahlian dan mengerjakan yang terbaik. Individu memiliki orientasi tujuan seperti ini biasanya akan mencari tugas-tugas dengan tingkat kesulitan yang menantang. Hal ini dikarenakan individu tersebut mempersepsikan tugas-tugas sebagai suatu peluang untuk mengembangkan kompetensinya.

Garcia, Restubog, Toledano, Tolentino dan Rafferty (2012), menyatakan bahwa ada dua gambaran dari hasil penelitian yang didapatkan, yaitu gambar pertama, pada high levels of student rating of parental support, hasilnya adalah signifikan dan terdapat hubungan positif yang kuat antara orientasi tujuan (learning goal orientation) dan efikasi diri dalam pemilihan karier (career decision making self efficacy). Sedangkan pada low levels of student rating of parential support, hasilnya tidak signifikan. Pada gambar kedua dari hasil penelitian Garcia et al. (2012), menunjukkan bahwa terdapat hubungan positif yang signifikan hanya pada hubungan antara orientasi tujuan belajar (learning goal orientation) dan efikasi diri dalam pemilihan karier (career decision making self efficacy) untuk low parental ratings of support saja.

Penelitian mengenai orientasi tujuan dilakukan oleh Bell dan Kozlowski (2002), penelitian tersebut berjudul Goal Orientation and Ability: Interactive Effects on Self Efficacy, Performance and Knowledge. Penelitian ini bertujuan untuk mengetahui hubungan secara langsung antara goal orientation dan cognitive ability serta interaksi di antara keduanya dengan efikasi diri, performansi dan pengetahuan di dalam konteks pembelajaran. Partisipan sebanyak 125 mahasiswa dari Midwestern yang terdiri dari $58 \%$ adalah wanita dan sisanya pria yang berusia 18-21 tahun. Penelitian ini menggunakan desain eksperimen dengan memberikan tugas berupa simulasi permainan yang berupa TANDEM (Computer Bases Radar Situation) serta pemberian skala goal orientation, selanjutnya akan diukur efikasi diri, performansi yang dihasilkan dan pengetahuan yang diperoleh. Hasil dari penelitian ini menunjukkan bahwa terdapat hubungan pembelajaran dengan performance goal orientation dari siswa. Learning goal orientation, berhubungan positif dengan efikasi diri, performansi dan pengetahuan siswa, selain itu ternyata performance goal orientation berhubungan secara negatif dengan salah satu hasil performansi.

Orientasi tujuan performansi secara konseptual dan empiris terpisah dari orientasi tujuan penguasaan (Harackiewicz, Baron, Tauer, Carter \& Elliot, 2000). Efek dari orientasi tujuan penguasaan materi yang positif menunjukkan bahwa orientasi tujuan performansi adalah negatif. Harackiewicz, et al (2000), telah melakukan penelitian yang menguji efek orientasi tujuan pengua-saan materi terpisah dari efek orientasi tujuan performansi. Orientasi tujuan performansi berhubungan dengan tingkat ketertarikan yang tinggi terhadap mata kuliah atau materi pelajaran.

Orientasi tujuan penguasaan dalam penelitian ini adalah fokus tujuan individu dalam meningkatkan kompetensi, berusaha mendapatkan keahlian, pantang menyerah dalam menghadapi kesulitan dan melakukan yang terbaik yang diketahui melalui skor pada skala orientasi tujuan penguasaan yang dikembangkan oleh Darwati (2003) karena konsep skala yang digunakan sama dengan teori yang digunakan oleh peneliti. Darwati (2003) menggunakan tiga aspek milik Ford dan Nichols (dalam Schunk, Meece \& Pintrich, 2004) yaitu, active-reactive style, approachavoidance style dan maintenance-change. 
Akhir-akhir ini menurut beberapa ahli mastery goals orientation (orientasi tujuan penguasaan) juga dibedakan atas dua hal, yaitu approach (pendekatan) dan avoidance (penginderaan) (Kaplan \& Maehr, 2007). Penginderaan ditemukan tidak berkaitan dengan strategi kognitif ataupun prestasi, tetapi berkaitan secara negatif seperti kecemasan dan ketakutan, serta untuk mendapatkan bantuan perawatan (Kaplan \& Maehr, 2007). Sebaliknya, pendekatan (approach) digambarkan sebagai motivasi dalam diri secara sungguh-sungguh untuk menggapai prestasi dan lebih berfokus pada kemungkinan untuk menyelesaikan tugas (Elliot, McGregor \& Gable, 1999).

Berdasarkan uraian di atas, hipotesis yang diajukan adalah bimbingan karier berpengaruh meningkatkan efikasi diri dalam pengambilan keputusan karier siswa.

\section{Metode}

\section{Subjek}

Pemilihan kriteria subjek penelitian ini adalah siswa SMA kelas XI yang memiliki skor efikasi diri dalam pengambilan keputusan karier rendah sampai sedang, kelas XI SMA dan belum pernah mendapatkan pelatihan perencanaan karier. Subjek penelitian berasal dari SMA $X$ di Yogyakarta kota. Subjek penelitian terdiri dari 62 siswa, yang dibagi menjadi dua kelompok, yaitu 32 subjek pada kelompok eksperimen dan 32 pada kelompok kontrol. Subjek penelitian terdiri dari 62 siswa, yang dibagi menjadi dua kelompok, yaitu 32 subjek pada kelompok eksperimen dan 32 pada kelompok kontrol. Akan tetapi subjek yang mengikuti seluruh rangkaian kegiatan bimbingan karier melalui pelatihan perencanaan karier kelompok eksperimen sebanyak 21 dan kelompok kontrol sebanyak 27 siswa.
Subjek pada kelompok eksperimen akan diberikan pelatihan perencanaan studi lanjut sebagai treatment layanan bimbingan karier.

Skala

Metode pengumpulan data yang digunakan dalam penelitian ini (1) berupa skala efikasi diri dalam pengambilan keputusan karier yang dikembangkan oleh Ardiyanti (2014), dengan menggunakan tiga aspek Bandura (1997), yaitu level (tingkat kesulitan), generality (rentang keluasan bidang) dan strength (tingkat kekuatan); (2) Skala orientasi tujuan penguasaan ini menggunakan skala orientasi tujuan penguasaan yang dikembangkan oleh Darwati (2003), dengan menggunakan tiga aspek Ford dan Nichols (dalam Schunk, Meece \& Pintrich, 2004), yaitu active-reactive style, approach-avoidance style dan maintenance-change.

\section{Manipulasi variabel independen}

Manipulasi yang digunakan dalam penelitian ini adalah salah satu teknik dari metode bimbingan karier yaitu pelatihan perencanaan studi lanjut. Modul penelitian disusun peneliti berdasarkan lima tahap perkembangan karier untuk perencanaan karier milik Jaffe dan Scott (dalam Kummerow, 1991) yaitu menilai diri sendiri, mengekplorasi peluang, membuat rencana, melakukan tindakan dan mengevaluasi hasil. Prosedur penelitian yang dilakukan yaitu melalui tahap persiapan: Meminta izin dan melakukan preliminary study untuk mendapatkan gambaran mengenai efikasi diri siswa dalam pengambilan keputusan karier pada siswa kelas XI SMA. Tahap persiapan instrument penelitian, yaitu adaptasi skala efikasi diri dalam pengambilan keputusan karier, penyusunan modul layanan bimbingan karier dan uji coba modul 
pelatihan. Alur pelaksanaan pelatihan atau eksperimen adalah penentuan subjek penelitian, yaitu 32 siswa kelas XI yang masuk kedalam kelompok eksperimen dan siwa dan konsekuensi yang diterima siswa apabila berpartisipasi dalam penelitian. Siswa diminta untuk menandatangani informed consent sebagai bukti kesediaan

Tabel 1.

Materi Bimbingan Karier pada Setiap Pertemuan

\begin{tabular}{cl}
\hline Pertemuan & \\
\hline 1 & Aktivitas 1: Pembukaan \\
& Aktivitas 2: Games dan Kontrak Belajar \\
& Aktivitas 3: Pemberian Pemahaman mengenai Bimbingan Karier yang akan Dilakukan \\
& Aktivitas 4: Penutup \\
& Aktivitas 1: Pembukaan \\
& Aktivitas 2: Jenis Ketrampilan yang Sesuai Untukku \\
& Aktivitas 3: Pembahasan dan Diskusi mengenai Jenis Ketrampilan yang Sesuai Untukku \\
& Aktivitas 4: Penutup \\
& Aktivitas 1: Pembukaan \\
& Aktivitas 2: Alternatif Jurusan yang Sesuai dengan Keterampilanku \\
& Aktivitas 3: Pembahasan dan Diskusi mengenai Alternatif Jurusan yang Sesuai dengan Keterampilanku \\
& Aktivitas 4: Penutup \\
& Aktivitas 1: Pembukaan \\
& Aktivitas 2: Merencanakan Masa Depan dengan Konsep “AKU” dan Masalahnya \\
& Aktivitas 3: Pembahasan dan Diskusi mengenai Merencanakan Masa Depan dengan Konsep "AKU” \\
& dan Masalahnya \\
& Aktivitas 4: Penutup \\
& Aktivitas 1: Pembukaan \\
& Aktivitas 2: Membuat dan Diskusi mengenai Rencana Jangka Pendek \\
& Aktivitas 3: Penutup \\
& Aktivitas 1: Pembukaan \\
& Aktivitas 2: Mengevaluasi Hasil yang Telah Dilakukan dan Membuat Pilihan Studi \\
& Aktivitas 3: Penutupan \\
\hline &
\end{tabular}

32 siswa kelas XI yang masuk kedalam kelompok kontrol di SMA X di Yogyakarta yang memiliki skor efikasi diri dalam pengambilan keputusan karier kategori rendah sampai sedang; Pemberian skala orientasi tujuan penguasaan dan tes pengetahuan kepada subjek penelitian baik kelompok eksperimen maupun kelompok kontrol; Penyampaian informed concent pada subjek penelitian kelompok eksperimen pada bulan januari 2017 sedangkan pada kelompok kontrol dilakukan pada bulan Maret 2017 setelah pelatihan pada kelompok eksperimen selesai. Peneliti menjelaskan mengenai bentuk keterlibatan berpartisipasi dalam penelitian; Pemberian pelatihan "Perencanaan Studi Lanjut" pada bulan Januari 2017 yang berlangsung di dalam kelas. Selanjutnya diberikan posttest dan tes pengetahuan; Menganalisis data penelitian kelompok eksperimen dan kelompok kontrol; dan Memberikan pelatihan pada kelompok kontrol sebagai tanggung jawab etika penelitian.

\section{Analisis Data}

Analisis data ini dilakukan untuk menguji perbedaan skor efikasi diri dalam pengambilan keputusan karier dari pretest, 
post test dan skor antara kelompok eksperimen dengan kelompok kontrol dengan orientasi tujuan penguasaan sebagai kovariabel karena orientasi tujuan penguasaan dianggap akan turut mempengaruhi efikasi diri dalam pegambilan keputusan karier. Analisis data dalam penelitian ini menggunakan analisis kovarian (Ancova) satu jalur melalui program SPSS.

\section{Hasil}

Penelitian ini berusaha menguji pengaruh bimbingan karier terhadap efikasi diri dalam pengambilan keputusan karier dan orientasi tujuan penguasaan sebagai kovariabel dengan membandingkan antara kelompok eksperimen dengan kelompok kontrol.

Verifikasi dilakukan untuk melihat variabel penyerta (orientasi tujuan penguasaan) bisa dijadikan kovariat atau ditunjukkan pada nilai $\mathrm{F}=4,583$ dengan signifikansi 0,016 ( $p>0,05)$.

Dikarenakan hasil antara orientasi tujuan penguasaan dengan efikasi diri dalam pengambilan keputusan karier tidak memiliki korelasi analisisnya diubah menjadi mixed anova (anava campuran).

Dari hasil analisis data menunjukkan bahwa bimbingan karier dengan memberikan pelatihan perencanaan studi lanjut dapat meningkatkan efikasi diri dalam pengambilan keputusan karier siswa. Hal ini dapat dilihat dari mean pada masing-masing kelompok (mean kelompok eksperimen 102,05 : 120,76 dan kelompok kontrol 87,63 : 88,52). Nilai mean kelompok eksperimen lebih tinggi dari pada kelompok kontrol yang disebabkan kelompok eksperimen mendapatkan pelatihan perencanaan studi lanjut sementara kelompok kontrol tidak.

Tabel 2.

Statistik Deskriptif

\begin{tabular}{lccccc}
\hline \multicolumn{1}{c}{ Kelompok } & Pengetesan & Mean & SD & Min & Maks \\
\hline Eksperimen & Pretest & 102,05 & 6,84 & 95 & 112 \\
& Posttest & 120,76 & 4,5 & 111 & 128 \\
\multirow{3}{*}{ Kontrol } & & & & 71 & 110 \\
& Pretest & 87,63 & 9,69 & 80 & 107 \\
\hline
\end{tabular}

tidak. Berikut hasil verifikasi bahwa korelasi antara orientasi tujuan penguasaan sebagai kovariat memiliki korelasi yang tidak signifikan dengan efikasi diri dalam pengambilan keputusan karier. Hasil korelasi menunjukkan nilai $r=-0,061$ dengan nilai signifikansi $0,680 \quad(p>0,05)$, artinya tidak ada korelasi antara efikasi diri dalam pengambilan keputusan karier dengan orientasi tujuan penguasaan, sehingga orientasi tujuan penguasaan tidak dapat dijadikan kovariat. Hasil verifikasi lainnya menunjukkan bahwa tidak adanya interaksi antara variabel orientasi tujuan penguasaan dengan variabel efikasi diri dalam pengambilan keputusan karier yang
Hasil analisis data menunjukkan bahwa ada pengaruh bimbingan karier dengan memberikan pelatihan perencanaan studi lanjut terhadap efikasi diri dalam pengambilan keputusan karier yang signifikan antara kelompok eksperimen dan kelompok kontrol. Pada kelompok eksperimen efikasi diri dalam pengambilan keputusan karier lebih tinggi dibandingkan dengan kelompok kontrol.

Dari hasil analisis di atas berarti hipotesis penelitian ini tidak dapat diterima. Karena hanya bimbingan karier yang berupa pelatihan perencanaan studi lanjut yang diberikan kepada kelompok eksperimen mampu meningkatkan efikasi 
diri dalam pengambilan keputusan karier dari pada kelompok kontrol dan orientasi tujuan sebagai kovariabel tidak terbukti karena orientasi tujuan penguasaan tidak mempe-ngaruhi efikasi diri dalam pengambilan keputusan karier.

Berikut ini ringkasan uji hipotesis efikasi diri dalam pengambilan keputusan karier pada tabel 3. peren-canan studi lanjut dapat meningkatkan skor efikasi diri dalam pengambilan keputusan karier pada kelompok eksperimen. Interaksi antara kelompok eksperimen dengan kelompok kontrol pada saat pretest dan posttest pada gambar 1.

\section{Diskusi}

Tabel 3.

Ringkasan Uji Hipotesis Efikasi Diri Dalam Pengambilan Keputusan Karier

\begin{tabular}{lcccccc}
\hline \multicolumn{1}{c}{ Source } & $\begin{array}{c}\text { Type III Sum } \\
\text { of Square }\end{array}$ & $d f$ & Mean Square & $F$ & Sig. & $\begin{array}{c}\text { Partial Eta } \\
\text { Squared }\end{array}$ \\
\hline Pengetesan & 2269,680 & 1 & 2269,680 & 125,869 & 0,001 & 0,732 \\
Pengetesan*Kelompok & 1876,680 & 1 & 1876,680 & 104,074 & 0,001 & 0,693 \\
Error (time) & 829,476 & 46 & 18,032 & & & \\
\hline
\end{tabular}

Pada penelitian ini saya ingin

Berdasarkan tabel 3 pada baris pengetesan*kelompok menunjukkan nilai $\mathrm{F}=104,074 \quad(\mathrm{p}<0,05)$ yang berarti terdapat interaksi antara pengetesan (pretest-posttest) menguji lebih lanjut apakah ada hubungan antara bimbingan karier dengan efikasi diri dalam pengambilan keputusan karier dan orientasi tujuan penguasaan sebagai

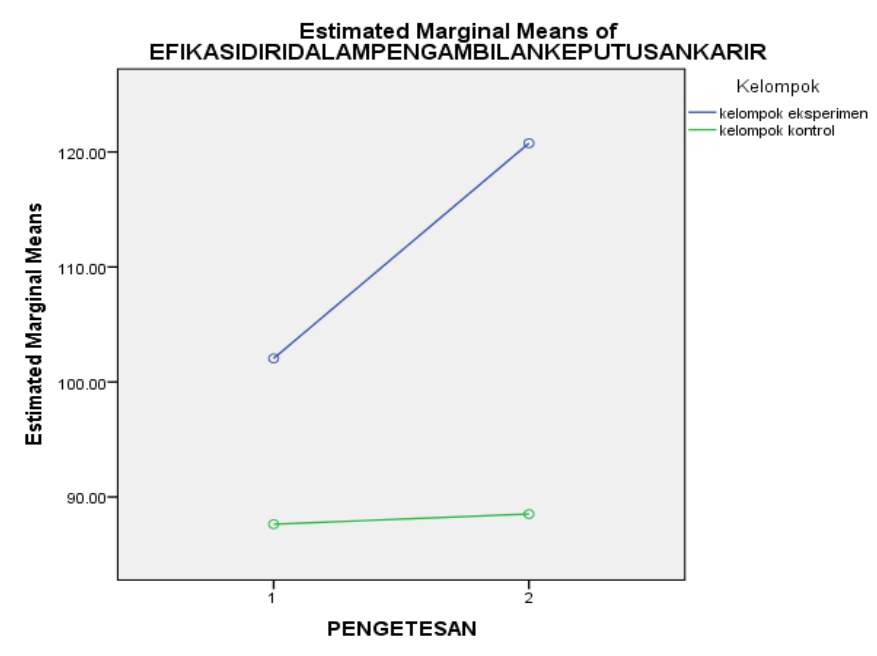

Gambar 1. Plot Kelompok Eksperimen dan Kelompok Kontrol

dengan kelompok (eksperimen-kontrol). Interaksi ini menunjukkan adanya perubahan skor pre menuju post yang berbeda secara signifikan pada kedua kelompok (eksperimen-kontrol). Hal ini berarti pemberian intervensi berupa bimbingan karier dengan memberikan pelatihan kovariabel. Dari hal ini berarti orientasi tujuan penguasaan tidak memberi pengaruh terhadap peningkatan efikasi diri dalam pengambilan keputusan karier.

Berbeda dengan hasil di atas, hasil yang didapat mengenai pengaruh bimbingan karier dengan efikasi diri dalam 
pengambilan keputusan karier menunjukkan bahwa kelompok eksperimen yang mendapatkan bimbingan karier mengalami peningkatan efikasi diri dalam pengambilan keputusan karier yang lebih tinggi dari pada kelompok kontrol. Hal ini menunjukkan bahwa bimbingan karier dengan memberikan pelatihan perencanaan studi lanjut dapat meningkatkan efikasi diri dalam pengambilan keputusan karier. Hasil penelitian ini mendukung penelitian yang dilakukan Mulyana (2009), yang menyimpulkan bahwa bimbingan karier melalui pelatihan perencanaan karier secara signifikan dapat meningkatkan efikasi diri dalam pengambilan keputusan karier. pelatihan ini juga mendukung penelitian Setyowati (2015), yang menemukan bahwa bimbingan karier berperan meningkatkan efikasi diri dalam keputusan karier.

Proses bimbingan karier melalui pelatihan perencanaan studi lanjut membantu peserta mengidentifikasi kemampuan diri dan minatnya. Selain itu, peserta juga difasilitasi untuk menganalisis kecocokan antara potensi, minat dengan peluang dari program studi yang diminati dengan mempertimbangkan faktor pendukung dan penghambatnya. Proses diskusi di kelas dengan dipandu trainer membuat individu mampu menentukan pilihan karier dan membuat perencanaan karier. Berdasarkan dinamika tersebut terbukti bahwa bimbingan karier melalui pelatihan perencanaan studi lanjut memberikan pengaruh dalam meningkatkan efikasi diri dalam pengam-bilan keputusan karier pada peserta.

Keberhasilan bimbingan karier melalui perencanaan studi lanjut dalam meningkatkan efikasi diri dalam pengambilan keputusan karier kelompok eksperimen ini didukung oleh penggunaan teori Jaffe dan Scott. Sebagaimana penelitian
Kusumaningrum (2012) dan Ardiyanti (2014), yaitu workshop bimbingan karier dan pelatihan perencanaan karier yang disusun berdasarkan teori Jaffe dan Scott terbukti dapat meningkatkan efikasi diri dalam pengambilan keputusan studi lanjut pada mahasiswa tingkat akhir dan pada siswa SMA. Semua sesi bimbingan karier melalui perencanaan studi lanjut disusun berdasarkan tahapan perencanaan karier Jaffe dan Scott (dalam Kummerow, 1991), yaitu menilai diri sendiri, mengeksplorasi peluang, menyusun rencana karier, melakukan tindakan dan evaluasi. Modul yang disusun diharapkan dapat dapat membantu siswa untuk membuat perencanaan studi lanjutnya ke jenjang pendidikan yang lebih tinggi sesuai dengan dirinya.

Bimbingan karier dalam penelitian ini teruji secara signifikan dapat meningkatkan efikasi diri dalam pengambilan keputusan karier pada kelompok eksperimen. Keberhasilan bimbingan karier dalam meningkatkan efikasi diri dalam pengambilan keputusan karier dapat terjadi salah satunya karena menggunakan pende-katan sosial kognitif. Teori sosial kognitif menurut Bandura menekankan pandangan tentang seseorang yang aktif dan sebagai pengguna proseproses kognisi untuk menggambarkan kejadian-kejadian, antisipasi masa depan, memilih tindakan dan berkomunikasi dengan orang lain (dalam Pervin \& John, 2001). Bandura dalam teorinya, menekankan pada pentingnya persepsi diri (efikasi diri) sebagai mediator kognitif dalam bertindak. Sambil mempertimbangkan tindakannya, seseorang membuat keputusan mengenai kemampuannya dalam melakukan tindakan tersebut (penilaian terhadap efikasi dirinya). Penilaian efikasi diri akan memengaruhi pikiran, emosi dan tindakan 
seseorang dalam mencapai tujuannya. Selanjutnya seseorang akan menyusun standar dan tujuan serta membuat penilaian mengenai kemampuan untuk menampilkan tugas atau melakukan tindakan (Pervin \& John, 2001)

$$
\text { Jika dikaitkan dengan proses }
$$

bimbingan karier, peserta dalam bimbingan karier ini sebelumnya menentukan target yang ingin dicapai sesuai dengan derajat keyakinan bahwa ia dapat memenuhi target itu dengan baik. Setelah itu, individu belajar dari pengalaman dirinya dan orang lain dengan cara refleksi diri dan melihat perilaku orang lain, kemudian menganalisisnya secara kritis sehingga ia menemukan pemahaman baru. Selama proses penemuan pemahaman baru, individu akan mengalami proses belajar dari pengalaman dirinya dan lingkungannya (pengalaman orang lain). Setelah menemukan pemahaman baru, individu akan menetap-kan tujuan dan menyusun rencana untuk mencapai tujuannya tersebut.

Selama proses bimbingan karier, peserta diberikan kesempatan berproses bersama dan belajar untuk memperoleh pemahaman baru. Peserta diberikan kesempatan berproses bersama dan belajar untuk memperoleh pengalaman baru. Peserta diberi kesempatan untuk bisa terbuka satu sama lain tentang pandangan, perasaan maupun pengalaman terhadap dirinya serta studi lanjut yang diketahuinya. Peserta juga mendapatkan dukungan dari peserta lain sehingga menambah keyakinan dan kemantapan tentang rencana studi lanjut yang dipilihnya. Proses bimbingan karier ini terbagi dalam 6 pertemuan yaitu membangun kenyamanan dan kedekatan, menilai diri sendiri, pandangan karier, membuat rencana, melakukan tindakan dan evaluasi hasil.

\section{Kesimpulan}

Ada pengaruh bimbingan karier terhadap efikasi diri dalam pengambilan keputusan karier. Bimbingan karier melalui pelatihan perencanaan karier terbukti dapat berperan aktif dalam meningkatkan efikasi diri dalam pengambilan keputusan karier. Tidak ditemukan hubungan antara orientasi tujuan penguasaan dengan efikasi diri dalam pengambilan keputusan karier.

\section{Saran}

Hasil penelitian menemukan bahwa ada pengaruh yang signifikan dari bimbingan karier melalui pelatihan perencanaan studi lanjut dengan efikasi diri dalam pengambilan keputusan karier pada kelompok eksperimen di SMA $X$ di Yogyakarta, dengan demikian diharapkan di SMA $X$ di Yogyakarta memberikan bimbingan karier lebih intensif kepada siswa supaya efikasi diri pada pengambilan karier siswa dapat meningkat.

Hasil uji korelasi menemukan bahwa tidak ada korelasi antara orientasi tujuan penguasaan dengan efikasi diri dalam pengambilan keputusan karier, oleh karena itu diharapkan untuk penelitian selanjutnya tidak menggunakan orientasi tujuan penguasaan sebagai kovariabel tetapi menggunakan variabel lain.

\section{Kepustakaan}

Ardiyanti, D. (2014). Pelatihan "PLANS" untuk meningkatkan efikasi diri dalam pengambilan keputusan karier pada siswa $S M A$. (Tesis tidak dipublikasi). Fakultas Psikologi Universitas Gadjah Mada, Yogyakarta.

Bandura, A. (1997). Self-efficacy. The exercise of control. New York: Freeman.

Bandura, A., \& Schunk, D. (1984). Enhancing self efficacy and achievement through rewards and 
goals : Motivation and information effects, (ed). The Journal of Educational Research, 76(1).

Bell, B. S., \& Kozlowski, S. W. J. (2002). Goal orientation and ability: Interactive effects on self efficacy, performance and knowledge. Journal of Applied Psychology, (87), 496-505.

Betz, N. E., \& Luzzo, D. A. (1996). Career assessment and the career decision-making self-efficacy scale. Journal of Career Assessment, (4), 413428.

Betz, N. E., Klein, K., \& Taylor, K. (1996). Evaluation of a short form of the career decision-making Selfefficacy Scale. Journal of Career Assessment, (4), 47-57.

Brown, D., \& Associates. (2007). Career choice and development $\left(4^{\text {th }}\right.$. Ed). San Francisco: Jossey-Bass.

Burns, G. N., Jasinski, D., Dunn, S., \& Fletcher, D. (2013). Academic support services and career decision making self efficacy in student athletes. Journal of The Career Development Quarterly, 61(2), 161-168.

Darwati, Y. (2003). Kecenderungan mencari bantuan dalam belajar matematika ditinjau dari orientasi tujuan. (Tesis tidak dipublikasi). Program Pascasarjana UGM, Yogyakarta.

Dweck, C. S., \& Legget, E. L. (1988). A Social; cognitive approach to motivation and personality. Journal of Psychological Review, 95, 256-273.

Elliot, A. J., McGregor, H. A., \& Gable, S. L. (1999). Achievement goals, study strategies, and exam performance: A meditational analysis. Journal of Educational Psychology, 91, 549-563.

Fogarty, G. J., \& McGregor-Bayne, H. (2008) Factors that influence career decisionmaking among elite athletes.
Australian Journal of Career Development, 17(3), 26-40.

Garcia, P. R. J. M., Restuborg, S. L. D., Toledano, L. S., Tolentini, L. R., \& Rafferty, A. E. (2012). Differential moderating effects of student and parentated support in the relationship between learning goal orientation and career decisionmaking self-efficacy. Journal of Career Assessment, 20, 22-33.

Harackiewicz, J. M., Baron, K. E., Tauer, J. M., Carter, S. S., \& Elliot, A. J. (2000). Short-term and long-term concequences of achievement goals in college predicting continued interest and performance over time. Journal of Education and Social Psychology, 94, 562-575.

Juntika, N. A. (2006). Bimbingan dan konseling dalam berbagai latar kehidupan. Bandung: PT. Revika Aditama.

Kaplan, A., \& Maehr, M. L. (2007). The contributions and prospects of goal orientation theory. Journal of Education Psychology Rev, 19, 141-184.

Kummerow, J. M. (1991). New direction in career planning. Palo Arto. California: CPP Book.

Kusumaningrum, D. S. (2012). Pengaruh workshop bimbingan karier terhadap efikasi diri dalam pengambilan keputusan karier. (Tesis tidak dipublikasi). Fakultas Psikologi Universitas Gadjah Mada, Yogyakarta.

Lyon, D. W., \& Kirby, E. G. (2000). The career planning essay. Journal of Management Education, 24, 276-287.

Mulyana, P. O. (2009). Peningkatan efikasi diri terhadap pengambilan keputusan karier melalui pelatihan perencanaan karier. (Tesis tidak dipublikasi). Fakultas Psikologi Universitas Gadjah Mada, Yogyakarta. 
Ormrod, J. E. (2009). Psikologi Pendidikan: Membantu siswa tumbuh dan berkembang. (Prof. Dr. Amitya Kumara). Edisi Keenam Jilid 2. Jakarta: Penerbit Erlangga.

Osipow, Samuel H. (1987). Theories of career development (Third Edition). Englewood Cliffs. New Jersey: Prentice-Hall, Inc.

Oweini, A. \& Abdo, R. (2000). An experimental career counseling workshop for lebanese secondary school students. The High School Journal, 83(2), 51-63.

Pervin, L. A. \& John, O. P. (2001). Personality: Theory and research ( $\left.2^{\text {th }} \mathrm{ed}\right)$. New York: Guill Ford Press.

Purnamasari, A. (2005). Efektivitas pelatihan perencanaan karier untuk meningkatkan kejelasan arah pilihan bidang minat karier pada mahasiswa semester III fakultas psikologi. (Tesis tidak dipublikasi). Fakultas Psikologi Universitas Gadjah Mada, Yogyakarta.

Santoso, E. I., \& Himam, F. (2014). Pengaruh berbagi pengetahuan dalam perencanaan karier terhadap efikasi diri para pencari kerja dalam membuat keputusan karier. Jurnal Intervensi Psikologi, 6(1), 1-24.

Santrock, J. W. (2003). Life-span development (seventh edition). New York: McGrawHill, Inc.

Schunk, D. H., Meece, J. R., \& Pintrich, P. R. (2014). Motivation In edication theory, research and applications. London: Pearsin Education Limited.

Setyowati, E. (2015) Hubungan efektivitas bimbingan karier dan orientasi masa depan dengan keputusan karier remaja. (Naskah dipublikasi). Universitas Muhammadiyah Surakarta.

Simamora, H. (2004). Manajemen sumber daya manusia. Yogyakarta: STIE YKPN.
Sukardi, D. K. (1987). Bimbingan karier di sekolah-sekolah. Jakarta Timur: Ghalia Indonesia.

Sukardi, D. K. (1994). Psikologi pemilihan karier. Jakarta: Rineka Cipta.

Supatmi, T. (2014). Pengembangan bahan informasi bimbingan pemilihan karier untuk meningkatkan kemampuan pengambilan keputusan karier siswa SMK rumpun jurusan ekonomi. Skripsi. Jurusan Ilmu Pendidikan FKIP Universitas Negeri Surakarta.

Wisudaningrum, E. (2012). Pengaruh orientasi tujuan pada pembelajaran terhadap efikasi diri mengikuti pelatihan peningkatan kompetensi. (Tesis tidak dipublikasi). Fakultas Psikologi Universitas Gadjah Mada, Yogyakarta.

Zweig, D. \& Webster, J. (2004). What are we measuring? an examination of the relationships between the big:five personality trait, goal orientation, and performance intentions. Personality and Individual Differences, 36(7), 16931708. 